\title{
Health-related effects of nutritionally modified foods of animal origin
}

\author{
P.M. Pisulewski ${ }^{1}$, M. Franczyk and R.B. Kostogrys \\ Agricultural University of Cracow, \\ Department of Human Nutrition, Faculty of Food Technology \\ al. 29 Listopada 46, 31-425 Kraków, Poland
}

\begin{abstract}
There are several reasons to modify the composition (notably fatty acid composition) of foods of animal origin. These reasons are: 1. the growing incidence of chronic diseases in Europe, 2. the growing evidence of health-promoting effects of bioactive components of animal origin such as polyunsaturated fatty acids (PUFA) and conjugated linoleic acid (CLA) isomers, 3. the development of nutritional strategies to modify animal product composition, and 4 . the advent of the idea of functional foods in Europe.

This review presents current examples of nutritional enrichment of foods of animal origin (dairy products, meat and eggs) with PUFA or CLA. Moreover it presents examples of health-related (functional) effects of the modified foods in experimental animals and humans. Feeding these foods to animal models or humans confirmed their functional properties, e.g., anti-obesity, antiatherogenic and anti-carcinogenic effects.

It was repeated after the European Consensus Document (Diplock et al., 1999), that the most pertinent aspect in communicating of health-related benefits of functional foods is that any claim of their functionality must be scientifically-based, i.e. it must be both objective and appropriate. Therefore the development of functional foods must rely on identification and validation of relevant biological markers of particular target functions and (or) the risk of a particular disease.
\end{abstract}

KEY WORDS: nutritional strategy, PUFA ( $n$-3), CLA isomers, nutritionally modified foods, milk, meat, eggs, functional properties

$\overline{\text { Corresponding }}$ author: e-mail: rrpisule@cyf-kr.edu.pl 


\section{INTRODUCTION}

It is generally accepted that from a strictly nutritional point of view, foods of animal origin (i.e. milk, meat and eggs) are optional and non-essential components of an adult human diet (Millward, 1999). Moreover, it is believed that appropriately planned vegetarian diets are healthful, nutritionally adequate, and provide health benefits in the prevention and treatment of chronic diseases (Nestle, 1999). This opinion is clearly reflected by current dietary guidelines, e.g., The Mediterranean Diet Pyramid (Willett et al., 1995; Trichopoulou and Vasilopoulou, 2000; Simopoulos, 2001) and The Food Guide Pyramid (USDA, 2000), in which foods of plant origin, as opposed to foods of animal group, are strongly recommended. The major advice of the USDA (2000) is to "choose a variety of grains daily, especially whole grains", "choose a variety of fruits and vegetables daily" and "choose a diet which is low in saturated fat and cholesterol and moderate in total fat". It should be also indicated that the consumption of foods of animal origin, as rich sources of saturated fatty acids and cholesterol, has been frequently associated with their negative impact on human health. According to WHO/FAO (2003) and WHO (2004), both the level of dietary fat intake and its composition are risk factors of several chronic diseases, including obesity, cardiovascular diseases (CVD), cancers and non-physiological inflammatory reactions. Interestingly, the fat intake is considered much less dangerous compared with the impact of fatty acid composition (Müller et al., 2003). Indeed, monounsaturated and polyunsaturated fatty acids have been reported to exert beneficial health-related effects on human health whereas consumption of saturated and trans fatty acids has been considered to be a risk factor of the above diseases (Bartnikowska and Obiedziński, 1997; Simopoulos 1999; Connor, 2000; Colandre et al., 2003).

At the same time, milk, meat and eggs occupy a pivotal position in the global food chain, which is rather unlikely to change in the foreseeable future, at least in Europe. This position is certainly due to their social, political, and economic role in our societies (Millward, 1999). For example, the average consumption of these products in Poland is relatively high and is not expected to decline (Table 1; GUS, 2004).

Table 1. The average consumption of milk, meat and eggs in Poland (monthly per capita) (GUS, 2004)

\begin{tabular}{lcc}
\hline Specification & 2002 & 2003 \\
\hline Meat, kg & 5.41 & 5.47 \\
fresh & 3.07 & 3.27 \\
processed meat & 2.20 & 2.20 \\
Fish, kg & 0.40 & 0.39 \\
Milk, L & 4.89 & 4.80 \\
cheese, kg & 0.84 & 0.86 \\
butter, kg & 0.34 & 0.35 \\
Eggs, units & 15.08 & 14.77 \\
\hline
\end{tabular}




\section{THE RATIONALE BEHIND CURRENT EFFORTS TO MODIFY ANIMAL PRODUCT COMPOSITION}

There are several reasons to modify the composition (notably fatty acid composition) of foods of animal origin. These reasons are: 1. the growing incidence of chronic diseases in Europe; 2. the growing evidence of healthpromoting effects of bioactive components of animal origin; 3 . the development of nutritional strategies to modify animal product composition, and 4. the advent of the idea of functional foods in Europe.

First, the major concern expressed recently by WHO (2004) is the growing incidence of chronic diseases in Europe. According to the above source, cardiovascular disease causes 4 million of death per year and cancers kill around 1 million adults each year in the Region. It was also stressed that around one third of cardiovascular disease cases is diet-related. The same is true for cancer cases. These diseases are strongly related to high-fat and high-cholesterol diets, and more importantly, to saturated fatty acid and trans fatty acid consumption in particular.

Second, the growing evidence of beneficial, health-related, effects of bioactive components of animal origin i.e. polunsaturated fatty acids ( $n-6$ and $n-3$ series) and conjugated linoleic acid (CLA) isomers has become a reality. Among them $n-3$ fatty acids have attracted particular attention. Indeed, these compounds as dietary components, were shown to exert anti-obesity, anti-atherogenic, anticarcinogenic, and immuno-modulatory effects (Simopoulos, 1999). The bestevidenced beneficial role of $n-3$ fatty acids is their ability to reduce the risk cardiovascular disease (Connor, 2000; Hasler, 2002; Kris-Etherton et al., 2004; Lopez-Garcia et al., 2004). Another bioactive component of animal origin is CLA. In fact, the term CLA refers to a group of positional and geometric (cis, trans) isomers of octadecaenoic acid (C18:2), of which the cis-9, trans-11 (rumenic acid) and trans-10, cis-12 are the most abundant. These compounds are naturally found in ruminant milk and meat (Lawson et al., 2001; Raes et al., 2004). Moreover, when fed to experimental animals and humans, they exerted several beneficial health-related effects, comparable to the effects of $n$-3 polyunsaturates (Fritche and Steinhart, 1998; Pisulewski et al., 1999; Roche et al., 2001; Azain, 2003).

Third, the nutritional strategies to improve the quality of food products of animal origin are a relatively new approach that has emerged at the interface of animal nutrition, food science and human nutrition. This approach has been effectively used to alter animal product composition to be more consistent with human dietary guidelines. Equally, it has been used to enhance health-related properties of foods of animal origin. In non-ruminants (poultry and pigs), this approach is based on the premis that dietary fatty acids are absorbed unaltered from the small intestine and directly incorporated into muscle and adipose tissue lipids (Leskanich and Noble, 1997; Gonzales-Esquerra and Leeson, 2001; 
Azain et al., 2003; Raes et al., 2004). In ruminants (sheep and cattle) effective modification of animal carcass fatty acid composition has been achieved either by direct feeding of plant oils (Scollan et al., 2001) or by protecting dietary oils from biohydrogrenation in the rumen (Kowalski et al., 1999; Demirel et al., 2004; Kitessa et al., 2004). In more detail, saturated and monounsaturated fatty acids are synthesized endogenously (in part), and their concentrations in carcass lipids are less influenced by dietary fat. On the other hand, polyunsaturated fatty acids cannot be synthesized in the body and their concentrations in intramuscular fat and adipose tissue respond rapidly to dietary alterations (Leskanich and Noble 1997; Bou et al., 2004; Demirel et al., 2004).

Fourth, the idea of functional foods is a new frontier in nutritional sciences. It reflects the changing concepts of food in human nutrition, from a past emphasis on meeting nutrient requirements to an emphasis on health-related effects of foods, helping to reduce the risk of chronic diseases. In view of the above, functional foods can be defined as those containing specific nutrients and (or) non-nutrients that affect human health, beyond what is traditionally known as nutritional effects. Thus, there is no precise and universally accepted definition of these foods. Consequently, it has been suggested to understand the term "a functional food" as a new idea, rather than a defined product (Bellisle et al., 1998; Diplock et al., 1999; Roberfroid, 2000, 2002). Accordingly, an ideal functional food is considered to be: 1. a conventional or everyday food; 2 . consumed as a part of the conventional diet; 3. composed of naturally occurring components; 4. enhancing target function(s) beyond its nutritive value; 5 . reducing the risk of disease, and 6 . having sound, scientifically-based and verified claims. As such, the above definition, covers all major features of functional foods and is meant to set guidelines for research and development in the field of modern human nutrition. In a more practical way, a functional food is defined as: 1. a natural food in which one of the components (nutrient or non-nutrient) has been naturally enhanced through special growing conditions; 2 . a food to which a component has been added to provide benefits (e.g., the addition of selected probiotic bacteria to improve gut health); 3. a food from which a component has been removed (e.g., the reduction of saturated fatty acids); 4. a food in which the nature of one or more components has been modified (e.g., protein hydrolysates in infant formulas); 5. a food in which the bioavailability of one or more components has been increased, and 6. any combination of the above possibilities. As indicated in the European Consensus Document (Diplock et al., 1999), the most pertinent aspect in communicating of health-related benefits of functional foods is that any claim of their functionality must be scientifically-based, i.e. it must be both objective and appropriate. Therefore the development of functional foods must rely on identification and validation of relevant biological markers of particular target functions and (or) the risk of a particular disease. More precisely, these markers can be classified 
according to whether they relate to: 1 . exposure to the food component under study (e.g., the level of this component itself or its metabolites in the body fluids or tissues); 2. enhanced target function(s) or biological responses (e.g., changes in concentrations of relevant metabolites, specific proteins, enzymes or hormones as possible responses to a functional component); 3. an appropriate endpoint of the reduced disease risk (e.g., progression and regression of atherosclerotic lesions), and 4. individual susceptibility or genetic polymorphism controlling the effect of the functional component under study (e.g., nutrient-gene interactions).

As indicated above, any claim of functional properties of foods must be scientifically-based and must rely on identification and validation of relevant biological markers of particular target functions and (or) the reduced risk of a particular disease. Consequently several experiments have been performed in which experimental animals or human subjects were fed functional foods of animal origin in order to evaluate their functional properties (Pisulewski and Kostogrys, 2003).

\section{FUNCTIONAL PROPERTIES OF FOOD PRODUCTS OF ANIMAL ORIGIN ENRICHED WITH POLYUNSATURATED FATTY ACIDS AND CONJU- GATED LINOLEIC ACID ISOMERS}

\section{Dairy products}

Milk consumption (notably milk fat) is commonly considered to have adverse effects on human health. The presence of saturated fatty acids and cholesterol in milk fat have been identified as a major factor leading to elevated concentrations of total cholesterol and its atherogenic (LDL-cholesterol) fraction in blood, thus resulting in increased risk of the cardiovascular disease (Schaefer, 2002; Muller et al., 2003). Interestingly, the trans fatty acid diet increased the ratio of LDL- to HDL- cholesterol much more than did the milk fat diet, thus indicating a profound detrimental role of these particular compounds (Aro et al., 1997).

However, there is also evidence, that intake of milk fat by human subjects may have several beneficial effects. For instance, dairy products did not promote gains in body weight or body fat mass in young women in an 1-year intervention trial (Gunther et al., 2005). Butter consumption resulted in lower postprandial lipaemia and triacylglycerol-rich chylomicron accumulation (an independent risk factor for coronary heart disease) in blood of young men when compared to the effects of olive or sunflower oil (Mekki et al., 2002). Also, consumption of dairy products was associated with a more favourable LDL particle size distribution in humans (i.e. fever small dense LDL particles); a predominace of these particles is a well-established risk factor of coronary heart diseases (Sjogren et al., 2004). 
Finally, milk fat consumption was not associated with cardiovascular risk factors and did not increase the risk of a first acute myocardial infraction in humans, in a prospective epidemiological trial (Warensjo et al., 2004).

Still, in spite of these findings, the intake of milk and dairy products contributes to a large proportion of the total and saturated fat intake (and cholesterol), thus implying a link between the consumption of these products and the risk of cardiovascular disease. Consequently, an efficient nutritional strategy to reduce adverse effects of milk fat consumption was proposed (Noakes et al., 1996). In the above experiment modified milk fat was obtained from cows fed a protected polyunsaturated lipid supplement. Human subjects in this study were offered two experimental diets containing either regular or modified dairy products. The favourable changes in the fatty acid profile of modified milk fat (decreased SFA and increased MUFA and PUFA content), induced significantly lower total plasma cholesterol and lower atherogenic LDL-cholesterol concentrations in the human subjects (Table 2), thus indicating a functional effect of the modified milk fat.

Table 2. Total cholesterol, its LDL and HDL fractions and triacylglycerols in human blood plasma as affected by dietary fat (Noakes et al., 1996)

\begin{tabular}{lcc}
\hline Specification & Standard fat ${ }^{1}$ & Modified fat $^{2}$ \\
\hline Total cholesterol, mmol/L & $6.50^{\mathrm{A}}$ & $6.22^{\mathrm{B}}$ \\
LDL, mmol/L & $4.49^{\mathrm{A}}$ & $4.25^{\mathrm{B}}$ \\
$\mathrm{HDL}, \mathrm{mmol} / \mathrm{L}$ & 1.30 & 1.28 \\
Triacylglycerols, mmol/L & 1.57 & 1.54 \\
\hline${ }_{\mathrm{A}, \mathrm{B}} \mathrm{P}<0.01$ & \\
${ }^{1}$ standard fat, \%: SFA 65.0; MUFA 22.8; PUFA 2.2 & \\
${ }^{2}$ modified fat, \%: SFA 50.4; MUFA: 35.3; PUFA: 9.1 &
\end{tabular}

More spectacular findings were reported for CLA-enriched dairy products (notably milk fat). The female rats fed CLA-enriched butter (Ip et al., 1999), consistently accumulated more total CLA in the mammary gland and other tissues (four- to six-fold more), compared with those fed pure CLA (threefold increase), at the same level of dietary intake. Moreover, CLA isomers (both free and incorporated into butter fat) exerted a strong anticarcinogenic effect by reducing the development of chemically-induced mammary tumors in the rats by $53 \%$ (Table 3 ). In a more recent experiment (Ritzenhalter et al., 2005), healthy breast-feeding women were offered CLA-enriched, cheddar cheese (rich in rumenic acid, i.e. cis-9, trans-11 CLA isomer). The treatment resulted in elevated rumenic acid plasma concentrations and prevented the significantdecline in infant rumenic acid intake from human milk, compared with control subjects (Table 4). At the same time, the above dietary treatment had no effect on total milk fat, plasma (e.g., Th cells and IL-2) and milk (e.g., sIgA) indices of immunity or selected risk factors for cardiovascular disease (e.g., plasma cholesterol and triacylglycerols). 
Table 4. Maternal daily intake of rumenic acid (cis-9, trans-11 CLA, mg) and milk rumenic acid concentrations in lactating women fed control, low CLA cheese and high CLA cheese diets (Ritzenhalter et al., 2005)

\begin{tabular}{lcccccccc}
\hline \multirow{2}{*}{ Specification } & \multicolumn{2}{c}{ Control } & & \multicolumn{2}{c}{ Low CLA cheese } & & \multicolumn{2}{c}{ High CLA cheese } \\
\cline { 2 - 3 } & $0 \mathrm{wk}$ & $8 \mathrm{wk}$ & & $0 \mathrm{wk}$ & $8 \mathrm{wk}$ & & $0 \mathrm{wk}$ & $8 \mathrm{wk}$ \\
\hline${\text { Intake, } \mathrm{mg} / \text { day }^{1}}^{155}$ & 160 & & 126 & 262 & & 152 & 477 \\
Milk fat concentration, $\mathrm{g} / 100 \mathrm{~g}^{2}$ & 0.30 & 0.26 & & 0.23 & 0.28 & & 0.31 & 0.37 \\
\hline
\end{tabular}

${ }_{1,2}$ significant treatment $\mathrm{x}$ time interaction $(\mathrm{P}<0.1)$

\section{Meat}

As indicated above, the consumption of saturated fatty acids and cholesterol in foods of animal origin (including meat), leading to elevated concentrations of total cholesterol and its atherogenic (LDL-cholesterol) fraction in blood, is a well-established risk factor for the cardiovascular disease. However, according to more recent findings, the impact of meat consumption on human health should be analysed in more detail. For instance, the effects on liporotein profile of lean beef, lean fish and poultry meat, incorporated into a diet with a high polyunsaturated to saturated fatty acid ratio (30\% energy from fat, $268 \mathrm{mg}$ cholesterol/d), were studied in hypercholesterolemic subjects (Beauchesne-Rondeau et al., 2003). The consumption of these diets exerted several beneficial effects, e.g., it reduced plasma total and atherogenic LDL-cholesterol (5-9\%), total triacylglycerols (19$25 \%)$ and decreased the ratio of total cholesterol to HDL-cholesterol (6-11\%), thus inducing antiathrerogenic changes in plasma lipid profile.

There is also considerable evidence showing a close association between meat consumption and cancer incidence (WHO, 2004). However, the above term meat refers to red meat and processed meat in particular, and includes beef, lamb and pork, but excludes poultry and fish. Also, a positive association between meat consumption and cancer is largely limited to cancers of colon and rectum, i.e. colo-rectal cancers. Possible causes underlying these associations include the effects of carcinogenic N-nitroso compounds (Bingham, 1999) produced in the human large intestine. On the other hand, recent epidemiological studies are less conclusive (Bingham et al., 2002). Not surprisingly, the recent European dietary guidelines prudently recommend: "Those who are not vegetarians are advised to moderate consumption of preserved meat e.g. sausages, salami, bacon, ham" (WHO/FAO, 2003).

There have been several attempts to alter fatty acid composition of regular pork by decreasing the SFA and increasing the PUFA content in tissue lipids. Subsequently, the modified pork was offered to human subjects to verify its potential health-related effects. In the experiment of Sandström et al. (2000), the incorporation of modified pork and pork products into human diets decreased 
significantly total plasma cholesterol (Table 5), thus showing functional properties of the modified pork. Surprisingly, no differences were observed in LDL-, HDL- or VLDL-cholesterol or in triacylglycerol concentrations. In a similar experiment (Stewart et al., 2001), regular and modified pork (with high content of polyunsaturated fatty acids), were incorporated into experimental diets offered to women subjects. The subjects consuming modified pork in their diets had significantly lower total plasma cholesterol and LDL-cholesterol (Table 6).

Table 5. Plasma total cholesterol its LDL and HDL fractions, triacylglycerols, and $\alpha$-tocopherol in human blood plasma as affected by dietary fat (Sandstrom et al., 2000)

\begin{tabular}{|c|c|c|c|}
\hline Specification & $\begin{array}{c}\text { Standard fat } \\
(\text { Standard diet })^{1}\end{array}$ & $\begin{array}{c}\text { Modified fat } \\
(\text { Standard diet }+ \\
\text { rapeseed oil })^{2} \\
\end{array}$ & $\begin{array}{c}\text { Modified fat } \\
(\text { Standard diet }+ \\
\text { rapeseed oil + vit. E) }\end{array}$ \\
\hline Total cholesterol, $\mathrm{mmol} / \mathrm{L}$ & $3.62^{\mathrm{a}}$ & $3.47^{\mathrm{b}}$ & $3.44^{\mathrm{b}}$ \\
\hline VLDL, $\mathrm{mmol} / \mathrm{L}$ & 0.18 & 0.16 & 0.18 \\
\hline $\mathrm{LDL}, \mathrm{mmol} / \mathrm{L}$ & 2.25 & 2.20 & 2.19 \\
\hline $\mathrm{HDL}, \mathrm{mmol} / \mathrm{L}$ & 1.19 & 1.18 & 1.15 \\
\hline Triacylglycerols, mmol/L & 0.69 & 0.63 & 0.69 \\
\hline$\alpha$-Tocopherol, $\mu \mathrm{mol} / \mathrm{L}$ & $18.2^{\mathrm{a}}$ & $16.9^{\mathrm{b}}$ & $17.8^{\mathrm{a}}$ \\
\hline
\end{tabular}

Table 6. Total cholesterol and its LDL and HDL fractions in human blood plasma as affected by dietary fat (Stewart et al., 2001)

\begin{tabular}{|c|c|c|}
\hline Specification & $\begin{array}{c}\text { Standard fat } \\
(\text { Standard diet })^{1}\end{array}$ & $\begin{array}{c}\text { Modified fat } \\
(\text { Standard diet }+ \text { soyabean oil })^{2}\end{array}$ \\
\hline Total cholesterol, $\mathrm{mmol} / \mathrm{L}$ & $4.01^{\mathrm{a}}$ & $3.39^{\mathrm{b}}$ \\
\hline $\mathrm{LDL}, \mathrm{mmol} / \mathrm{L}$ & $2.33^{\mathrm{a}}$ & $1.78^{\mathrm{b}}$ \\
\hline $\mathrm{HDL}, \mathrm{mmol} / \mathrm{L}$ & 1.38 & 1.19 \\
\hline
\end{tabular}

More recently a rat model has been used to determine health-related effects of CLA-enriched beef. As could be expected, feeding CLA-enriched beef to rats (Mir et al., 2003) increased CLA concentration in lipids of liver, inguinal fat and retroperiotoneal fat compared with control animals. More importantly, apparent anti-obesity effects were evidenced. In rats fed the CLA-enriched beef, the adipocyte numbers per unit weight fat, both inguinal and retoperitoneal, were reduced by 42 and $49 \%$, respectively. Also, CLA-enriched beef decreased the 
total cell number in the two above fat pads by 39 and 51\%, respectively (Table 7). Recently, a detailed statistical analysis of anti-obesity effects of synthetic CLA and CLA-enriched beef was reported by Goonewerdene et al. (2004). It clearly indicated that feedding CLA-enriched beef would exert an antiobesity effect only if sufficient levels of the specific CLA isomer were present in the meat.

Table 7. Effects of CLA-enriched beef meat on adipose tissue in rats (Mir et al., 2003)

\begin{tabular}{lcc}
\hline Specification & Control beef & CLA-enriched beef \\
\hline Retroperitonel fat: & & \\
$\quad$ Weight, $\mathrm{g}$ & 7.09 & 6.89 \\
$\mathrm{n} \times 10^{6}$ cells $/ \mathrm{mg}$ & $2.22^{\mathrm{a}}$ & $1.12^{\mathrm{b}}$ \\
total cell number, $\mathrm{n} \times 10^{9}$ & $16.70^{\mathrm{a}}$ & $8.24^{\mathrm{b}}$ \\
& & \\
Inguinal fat: & 7.99 & 7.74 \\
weight, $\mathrm{g}$ & $2.50^{\mathrm{a}}$ & $1.44^{\mathrm{b}}$ \\
$\mathrm{n} \times 10^{6}$ cells $/ \mathrm{mg}$ & $19.43^{\mathrm{a}}$ & $11.83^{\mathrm{b}}$ \\
total cell number, $\mathrm{n} \times 10^{9}$ & & \\
\hline
\end{tabular}

a,b $\mathrm{P}<0.05$

Eggs

Generally, eggs are low calorie source of high-quality protein and the yolk lipids that serve to enhance the bioavailability of nutrients such as lutein and zeaxanthin. More importantly, eggs are excellent sources of important watersoluble (e.g., $\mathrm{B}_{2}, \mathrm{~B}_{12}$ and folic acid,) and fat souluble (e.g., A and D) vitamins, and microelements (e.g., Fe, I and Se). However, despite these benefits, the perception of eggs as rich sources of cholesterol (200-250 mg/egg), has resulted in dietary cholesterol intake $(<300 \mathrm{mg} / \mathrm{d})$ and egg consumption restictions, over the last 2025 years (USDA, 2000). These restrictions were based on the assumption that dietary cholesterol, e.g., of egg origin, raises plama cholesterol levels which in turn, are associated with increased risk of cardiovascular disease in humans.

In contrast to the above assumption, several epidemiological studies have demonstrated the lack of a relationship between egg intake and the risk of cardiovascular disease (Herron and Fernandez, 2004). For instance the lack of a relationship between egg intake and coronary heart disease was demonstrated in human subjects (Song and Kerner, 2000). In the same line, an epidemiological study that examined dietary patterns of 117000 nurses and health profesionals, over 14 years, did not find any difference in the relative risk for coronary heart disease between subjects consuming less than one egg per week and those consuming more than one egg per day (Hu et al., 1999). It could be explained by the fact that in humans, manipulation of dietary cholesterol intake, modified or had no effect on endogenous cholesterol synthesis, while affecting its plasma concentrations only marginally (Howell et al., 1997; Jones, 1997). Still, the advice to limit dietary cholesterol seems to be valid, at least in the populations in which 
egg consumption makes relatively large contribution to total dietry cholesterol intake (Weggemans et al., 2001; Nakamura et al., 2004)

It should be also emphasized that hypercholesterolaemia is no longer considered the major risk factor of cardiovascular disease. Alternatively, atherosclerosis is defined as an inflammatory disease that begins with dysfunction of the vascular endothelium (Ross, 1999). Furthermore, the blood concentration of the inflammatory marker C-reactive protein (CRP) is a stronger predictor of cardiovascular disease than is atherogenic LDL-cholesterol (Ridker et al., 2002).

In the context of this review, eggs are ideal targets for nutritional modification. Indeed, feeding laying hens both polyunasturated fatty acids (e.g., Farrell, 1998) or CLA isomers (e.g., Szymczyk et al., 2001) resulted in their efficient and homogenous incorporation into egg-yolk lipids. Moreover, the modified egg-lipid profile refelected closely that of dietary fat. There have been also attempts to assess health-related properties of eggs enriched with the above bioactive compounds. In the study of Farrell (1998), laying hens fed different combinations of plant and fish oils, produced eggs enriched with $n-3$ polyunsaturated fatty acids; the most spectacular effect was the reduced ratio of $n-6$ to $n-3$ polyunsaturated fatty acids. Subsequently, the modified eggs were offered ( 7 eggs per week, for 24 weeks) to human subjects. Interestingly, there were no significant differences in plasma lipid components among treatment groups consuming ordinary (control) and the modified eggs. However, the subjects consuming the modified eggs showed significant increases in plasma EPA, DHA and total $n-3$ polyunsaturated fatty acid concentrations, compared to control subjects. Also, the modified eggs favourably reduced the plasma ratio of $n-6$ to $n-3$ polyunsaturated fatty acids (Table 8). Despite a large number of trials conducted to obtain CLA-enriched eggs, no attempts were made to verify their functional properties in human subjects. Instead, the potential plasma cholesterol-lowering properties of CLA-enriched egg yolks were studied in rats (Szymczyk et al., 2002). The CLA-enriched egg yolks were obtained from hens fed the CLA-supplemented commercial feed mixture (1.5\% dietary CLA).

Table 8. Polyunsaturated fatty acid (n-3) content in blood plasma of subjects consuming 7 eggs/week as affected by the source of fat used to modify egg lipid composition \% of total fatty acids (Farrell, 1998)

\begin{tabular}{lcccc}
\hline Specification & Control & Fish oil & $\begin{array}{c}\text { Fish oil } \\
\text { linseed oil }\end{array}$ & $\begin{array}{c}\text { Fish oil } \\
\text { linseed oil } \\
\text { rapeseed oil }\end{array}$ \\
\hline $\mathrm{C} 18: 3$ & 0.83 & 1.22 & 1.27 & 1.36 \\
$\mathrm{C} 20: 5$ & $0.60^{\mathrm{b}}$ & $0.91^{\mathrm{a}}$ & $0.78^{\mathrm{ab}}$ & $0.93^{\mathrm{a}}$ \\
$\mathrm{C} 22: 5$ & $0.42^{\mathrm{b}}$ & $0.57^{\mathrm{a}, \mathrm{b}}$ & $0.71^{\mathrm{a}}$ & $0.58^{\mathrm{a}, \mathrm{b}}$ \\
$\mathrm{C} 22: 6$ & $1.26^{\mathrm{b}}$ & $2.15^{\mathrm{a}}$ & $2.14^{\mathrm{a}}$ & $1.85^{\mathrm{a}, \mathrm{b}}$ \\
Total & $3.28^{\mathrm{b}}$ & $5.03^{\mathrm{a}}$ & $5.11^{\mathrm{a}}$ & $4.93^{\mathrm{a}}$ \\
$\mathrm{n}-6 / \mathrm{n}-3$ & $12.20^{\mathrm{b}}$ & $6.51^{\mathrm{a}}$ & $7.06^{\mathrm{a}}$ & $7.70^{\mathrm{a}}$ \\
\hline
\end{tabular}

a,b $\mathrm{P}<0.05$ 
Subsequently, the rats were fed either a regular egg-yolk diet or modified eggyolk diet. In spite of adverse effects of CLA isomers on fatty acid composition of egg-yolk lipids, the rats fed CLA-enriched egg yolks showed favourable changes in plasma lipoproteins: plasma total cholesterol and LDL-cholesterol tended to decrease, whereas concentrations of HDL-cholesterol were increased (Table 9). Also, liver cholesterol was significantly decreased in rats fed the CLAenriched egg yolks ( $7.8 \mathrm{vs} 4.7 \mathrm{mg} / \mathrm{g})$. The above changes can be considered to be preliminary indices of functional (i.e. hypocholesterolaemic) effects of CLAenriched eggs, at least in rats.

Table 9. Total cholesterol, its LDL and HDL fractions and triacylglycerols in blood plasma of rats fed standard and CLA-enriched egg yolks (Szymczyk et al., 2002)

\begin{tabular}{lcc}
\hline Specification & $\begin{array}{c}\text { Standard } \\
\text { egg yolks }\end{array}$ & $\begin{array}{c}\text { CLA-enriched } \\
\text { egg yolks }\end{array}$ \\
\hline Total cholesterol, mg/dL & 78.3 & 74.7 \\
LDL, mg/dL & 31.7 & 24.3 \\
HDL, mg/dL & 46.6 & 50.6 \\
HDL/total cholesterol & 0.59 & 0.67 \\
Triacylglcerols, mg/dL & 170.3 & 171.4 \\
\hline
\end{tabular}

${ }^{1}$ standard egg yolks, \%: SFA 31.0; MUFA 49.1; PUFA 19.3

${ }^{2}$ CLA-enriched egg yolks, \% : SFA 53.1; MUFA 26.0; PUFA 20.3

\section{REFERENCES}

Aro A., Jauhiainen M., Partanen R., Salminen I., Mutanen M., 1997. Steraic acid, trans fatty acids, and dairy fat: effects on serum and lipoprotein lipids, apolipoproteins, lipoprotein (a), and lipid transfer proteins in healthy humans. Amer. J. Clin. Nutr. 65, 1419-1426

Azain M.J., 2003. Conjugated linoleic acid and its effects on animal products and health in single stomached animals. Proc. Nutr. Soc. 62, 319-328

Bartnikowska E., Obiedziński M., 1997. Unsaturated trans fatty acids - nutritional problem? Pol. J. Food Nutr. Sci. 6/47 (3), 4-24

Beauchesne-Rondeau E., Gascon A., Bergeron J., Jacques H., 2003. Plasma lipids and lipoproteins in hypercholesterolemic men fed a lipid-lowering diet containing lean beef, lean fish, or poultry. Amer. J. Clin. Nutr. 77, 587-593

Bellisle F., Diplock A.T., Hornstra G., Kolezko B., Roberfroid M.B., Salminen S., Saris W.H.M. (Editors), 1998. Functional Food Science in Europe. Brit. J. Nutr. 80, Suppl. 1, S1-S193

Bingham S.A., 1999. High-meat diets and cancer risk. Proc. Nutr. Soc. 58, 243-248

Bingham S.A., Hughes R., Cross A.J., 2002. Effect of white versus red meat on endogenous Nnitrosation in the human colon and further evidence of a dose-response. J. Nutr. 132, 3522S$3525 \mathrm{~S}$

Bou R., Guardiola F., Tres A., Barroeta A.C., Codony R., 2004. Effects of dietary fish oil, $\alpha-$ tocopheryl acetate, and zink supplementation on the composition and consumer acceptability of chicken meat. Poultry Sci. 83, 282-292 
Colandre M.E., Diez R.S., Bernal C.A., 2003. Metabolic effects of trans fatty acids in an experimental dietary model. Brit. J. Nutr. 89, 631-638

Connor W.E., 2000. Importance of $n-3$ fatty acids in health and disease. Amer. J. Clin. Nutr. 71, Suppl., 171S-175S

Demirel G., Wachira A.M., Sinclair L.A., Wilkinson R.G., Wood J.D., Enser M., 2004. Effects of dietary $n-3$ polyunsaturated fatty acids, breed and dietary vitamin E on the fatty acids of lamb muscle, liver and adipose tissue. Brit. J. Nutr. 91, 551-565

Diplock A.T., Aggett P. J., Ashwell M., Bornet F., Fern E.B., Roberfroid M.B., 1999. Scientific Concepts of Functional Foods in Europe: Consensus Document. Brit. J. Nutr. 81, Suppl. 1, 1-27

Farrell D.J., 1998. Enrichment of hen eggs with n-3 long-chain fatty acids and evaluation of enriched eggs in humans. Amer. J. Clin. Nutr. 68, 538-544

Fritche J., Steinhart H., 1998. Analysis, occurence, and physilogical propereties of trans fatty acids (TFA) with particular emphasis on conjugated linoleic acid isomers (CLA) - a review. Fett Lipid 100, 190-210

Gonzales-Esquera R., Leeson S., 2001. Alternatives for enrichment of eggs and chicken meat with omega-3 fatty acids. Can. J. Anim. Sci. 81, 295-305

Goonewardene L.A., Mir P.S., Wang Z., Okine E.K., Mir Z., He M., 2004. Study of carcass, organ, myscle, fa tissue weight, and concentration in rats fed CLA or its precursors by principal component analysis. Can. J. Anim. Sci. 84, 537-543

Gunther C.W., Legowski P.A., Lyle R.M., McCabe G.P., Eagan M.S., Peacock M., Teegarden F., 2005. Dairy products do not lead to alterations in body weight or fat mass in young women in a 1-y intervention. Amer. J. Clin. Nutr. 81, 751-756

GUS, 2004. Polish Republic Statistical Yearbook (in Polish). GUS, Warszawa

Hasler C.M., 2002. Functional foods: benefits, concerns and challenges - a position paper from the American Council on Science and Health. J. Nutr. 132, 3772-3781

Herron K.L., Fernandez M.L., 2004. Are the current dietary guidelines regarding egg consumption appropriate ? J. Nutr. 134, 187-190

Howell W.H., McNamara D.J., Tosca M.A., Smith B.T., Gaines J.A., 1997. Plasma lipid and lipoprotein responses to dietary fat and cholesterol: a meta-analysis. Amer. J. Clin. Nutr. 65, $1747-1764$

Hu F.B., Stampfer M.J., Rimm E.B., Manson J.E., Ascherio A., Colditz G.A., Rosner B.A., Spigelman D., Speizer F.E., Sacks F.M., Hennekens C.H., Willett W.C., 1999. A prospective study of egg consumption and risk of cardiovascular disease in men and women. J. Amer. Med. Assoc. 281, 1387-1394

Ip C., Banni S., Angioni E., Carta G., McGinley J., Thompson H.J., Barbano D., Bauman D., 1999. Conjugated linoleic acid-enriched butter fat alters mammary gland morphogenesis and reduces cancer risk in rats. J. Nutr. 129, 2135-2142

Jones P.J.H., 1997. Regulation of cholesterol biosynthesis by diet in humans. Amer. J. Clin. Nutr. $66,438-446$

Kitessa S.M., Gulati S.H., Simos G.C., Ashes J.R., Scott T.W., Fleck E., Wynn P.C., 2004. Supplementation of grazing dairy cows with rumen-protected tuna oil enriches milk fat with $n$-3 fatty acids without affecting milk production or sensory characteristics. Brit. J. Nutr. 91, 271-277

Kowalski Z.M., Pisulewski P.M., Spanghero M., 1999. Effects of calcium soaps of rapeseed fatty acids and protected methionine on milk yield and composition in dairy cows. J. Dairy Res. 66, 475-487

Kris-Etherton P.M., Hecker K.D., Binkoski A.E., 2004. Polyunsaturated fatty acids and cardiovascular health. Nutr. Rev. 62, 414-426 
Lawson R.E., Moss A.R., Givens D.I., 2001. The role of dairy products in supplying conjugated linoleic acid to man's diet: a review. Nutr. Res. Rev. 14, 153-172

Leskanich C.O., Noble R.C., 1997. Manipulation of the $n-3$ polyunsaturated fatty acid composition of avian eggs and meat. World Poultry Sci. J. 53, 155-183

Lopez-Garcia E., Schulze M.B., Manson J.E., Meigs J.B., Albert Ch.M., Rifai N., Willett W.C., Hu F.B., 2004. Consumption of ( $n-3)$ fatty acids is related to plasma biomarkers of inflammation and endothelial activation in women. J. Nutr. 134, 1806-1811

Mekki N., Charbonnier M., Borel P., Leonardi J., Juhel Ch., Portugal H., Lairon D., 2002. Butter differs from olive oil and sunflower oil in its effects on postprandial lipemia and triacylglycerolrich lipoproteins after single mixed meals in healthy young men. J. Nutr. 132, 3642-3649

Millward D.J., 1999. The nutritional value of plant-based diets in relation to human amino acid requirements. Proc. Nutr. Soc. 58, 249-260

Mir P.S., Okine E.K., Goonewardene L., He M.L., Mir Z., 2003. Effects of synthetic conjugated linoleic acid (CLA) or bio-formed CLA as high CLA beef on rat growth and adipose tissue development. Can. J. Anim. Sci. 83, 583-592

Müller H., Lindman A.S., Brantsaeter A.L., Pedersen J.I., 2003. The serum LDL/HDL cholesterol ratio is influenced more favorably by exchanging saturated with unsaturated fat than by reducing saturated fat in the diet of women. J. Nutr. 133, 78-83

Nakamura Y., Okamura T., Tamaki S., Kodowaki T., Hayakawa T., Kita Y., Okayama A., Ueshima H., 2004. Egg cosumption, serum cholesterol, and cause-specific and all-cause mortlity: the National Integrated Project for Prospective Observation of Non-communicable diseases and its Trends in the Aged, 1980 (NIPPON DATA80). Amer. J. Clin. Nutr. 80, 58-63

Nestle M., 1999. Animal vs. plant foods in human diets and health: is the historical record unequivocal. Proc. Nutr. Soc. 58, 211-218

Noakes M., Nestel P.J., Clifton P.M., 1996. Modifying the fatty acid profile of diary products through feedlot technology lowers plasma cholesterol of humans consuming the products. Amer. J. Clin. Nutr. 63, 42-46

Pisulewski P.M., Kostogrys R.B., 2003. Functional properties of foods of animal origin and methods of their assessment. Pol. J. Food. Nutr. Sci. 12 (S1), 65-73

Pisulewski P.M., Szymczyk B., Hanczakowski P., Szczurek W., 1999. Conjugated linoleic acid (CLA) as a functional component of foods of animal origin (in Polish). Post. Nauk rol. 46 (6), 3-16

Raes K., De Smet S., Demeyer D., 2004. Effects of dietary fatty acids on incorporation of long chain polyunsaturated fatty acids and conjugated linoleic acid in lamb, beef and pork meat. Anim. Feed Sci. Tech. 113, 199-221

Ridker P.M., Fifai N., Rose L., Buring J.E., Cook N.R., 2002. Comparison of C-reactive protein and low-density lipoprotein cholesterol levels in the prediction of first cardiovascular disease. N. Engl. J. Med. 347, 1557-1565

Ritzenhalter K.L., McGuire M.K., McGuire M.A., Shulz T.D., Koepp A.E., Luedecke L.O., Hanson T.W., Dasgupta N., Chew B.P., 2005. Consumption of conjugated linoleic acid (CLA) isomer from CLA-enriched cheese does not alter milk fat or immunity in lactating women. J. Nutr. 135, $422-430$

Roberfroid M., 2000. Concepts and strategy of functional food science: the European perspective. Amer. J. Clin. Nutr. 71, 1660-1664

Roberfroid M.B., 2002. Global view on functional foods: European perspectives. Brit. J. Nutr. 88, Suppl. 2, S133-S138

Roche H.M., Noone E., Nugent A., Gibney M.J., 2001. Conjugated linoleic acid: a novel therapeutic nutrient? Nutr. Res. Rev. 14, 173-187 
Ross R., 1999. Atherosclerosis - an inflammatory disease. N. Engl. J. Med. 340, 115-126

Sandstrőm B., Bügel S., Lauridsen Ch., Nielsen F., Jensen C., Skibsted L., 2000. Cholesterol-lowering potential in human subjects of fat from pigs fed rapeseed oil. Brit. J. Nutr. 84, 143-150

Schaefer RJ., 2002. Lipoproteins, nutrition, and heart disease. Amer. J. Clin. Nutr. 75, 191-212

Scollan N.D., Choi N-J., Hurt E., Fisher A.V., Enser M., Wood J.D., 2001. Manipulating the fatty acid composition of muscle and adipose tissue in beef cattle. Brit. J. Nutr. 85, 115-124

Simopoulos A.P., 1999. Essential fatty acids in health and chronic disease. Amer. J. Clin. Nutr. 70, Suppl., 560S-569S

Simopoulos A.P., 2001. The Mediterranean diets: what is so special about the diet of Greece ? The scientific evidence. J. Nutr. 131, 3065S-3073S

Sjogren P., Rosell M., Skoglund-Andersson C., Zdravkovic S., Vesseby B., de Faire U., Hamsten A., Hellenius M.-L., Fischer R.M., 2004. Milk-derived fatty acids are associated with more favorable LDL particle size distribution in healthy men. J. Nutr. 134, 1729-1735

Song W.O., Kerner J.M., 2000. Nutritional contribution of eggs to American diets. Amer. Coll. Nutr. $19,556 \mathrm{~S}-562 \mathrm{~S}$

Stewart J.W., Kaplan M.L., Beitz D.C., 2001. Pork with a high content of polyunsaturated fatty acids lowers LDL cholesterol in women. Amer. J. Clin. Nutr. 74, 179-187

Szymczyk B., Pisulewski P.M., 2002. Feeding conjugated linoleic acid-enriched egg yolks alters serum lipid profile in adult rats. Ann. Anim. Sci. 2, 171-178

Szymczyk B., Pisulewski P.M., Szczurek W., Hanczakowski P., 2001. Effects of conjugated linoleic acid on growth performance, feed conversion efficiency and subsequent carcass quality in broiler chickens. Brit. J. Nutr. 85, 465-473

Trichopoulou A., Vasilopoulou E., 2000. Mediterranean diet and longevity. Brit. J. Nutr., Suppl. 2, S205-S209

USDA, 2000. "Nutrition and Your Health: Dietary Guidelines for Americans". $5^{\text {th }}$ Edition

Warensjo E., Jansson J.-H., Berglund L., Boman K., Ahren B., Weinehall L., Lindahl B., Hallmans G., Vesseby B., 2004. Estimated intake of milk fat is negatively associated with cardiovascular risk factors and does not increase the risk of a first acute myocardial infraction. Brit. J. Nutr. 91, 635-642

Weggemans R.M., Zock P.L., Katan M.B., 2001. Dietary cholesterol from eggs increases the ratio of total cholesterol to high-density lipoprotein cholesterol in humans: a meta-analysis. Amer. J. Clin. Nutr. 73, 885-189

WHO, 2004. „Food and Health in Europe; a New Basis for Action”. WHO Regional Publications. European Series: No. 96. Copenhagen

WHO/FAO, 2003. „Diet, Nutrition and the Prevention of Chronic Diseases”. WHO Technical Report Series: No. 916. Geneva

Willet W.C., Sacks F., Trichopoulou A., Drescher G., Ferro-Luzi A., Helsing E., Trichopoulous D., 1995. Mediterranean diet pyramid: a cultural model for healthy eating. Amer. J. Clin. Nutr. 61, Suppl., 1402S-1406S 


\section{STRESZCZENIE}

Prozdrowotne właściwości produktów pochodzenia zwierzęcego, uzyskanych na drodze modyfikcji żywieniowej

Rosnąca świadomość potrzeby modyfikowania składu produktów pochodzenia zwierzęcego (głównie składu kwasów tłuszczowych) wynika z: 1. narastania epidemii chorób chronicznych w Europie (układu krążenia, nowotworów, otyłości), 2. identyfikacji bioaktywnych składników pochodzenia zwierzęcego, m.in. wielonienasyconych kwasów tłuszczowych i izomerów sprzężonego kwasu linolowego (CLA), 3. rozwoju żywieniowych strategii modyfikowania składu produktów pochodzenia zwierzęcego oraz 4. sformułowania idei żywności funkcjonalnej w Europie.

Niniejszy przegląd przedstawia współczesne prace poświecone wzbogacaniu produktów pochodzenia zwierzęcego (mleka, mięsa i jaj) w wielonienasycone kwasy tłuszczowe i sprzężony kwas linolowy (CLA), na drodze manipulacji żywieniowej. Ponadto wskazuje na prozdrowotne (funkcjonalne) efekty zastosowania tak zmodyfikowanych produktów w żywieniu zwierząt doświadczalnych i ludzi. Podawanie tych produktów zwierzętom modelowym oraz ludziom potwierdziło ich właściwości funkcjonalne, m.in. przeciwmiażdżycowe, przeciwnowotwowe i przeciwlipidemiczne.

Uznano za słuszny pogląd wyrażony w European Consensus Document (Diplock i in., 1999), że warunkiem propagowania prozdrowotnych właściwości żywności funkcjonalnej jest ich oparcie na obiektywnych dowodach naukowych. Rozwój żywności funkcjonalnej musi być zatem wsparty identyfikacją miarodajnych parametrów biologicznych, charakteryzujących określone funkcje fizjologiczne. 